\title{
Studies on Performance of a Rotavator as Affected by its $\lambda$-Ratio
}

\author{
Abhishek Kumar ${ }^{*}$ and R.N. Pateriya \\ Farm Machinery and Power Engineering Department, \\ G. B. Pant University of Agriculture and Technology, Uttarakhand, India \\ *Corresponding author
}

\section{Keywords}

Negative draft, $\lambda$ ratio, Fuel consumption, Power consumption, Forward speed and rotational speed

Article Info

\section{Accepted:}

17 January 2021 Available Online: 10 February 2021
A Rotavator or rotary cultivator is the important secondary tillage implement as it provides greater degree of pulverization soil. It is an active tillage implement designed for preparing land suitable for sowing seeds or mixing manure or fertilizer into the soil. It breaks the soil clod into fine tilth by its rotary action of blades. It offers an advantage of rapid seedbed preparation and reduced draft compared to conventional tillage. However, a rotavator may produce the same degree of soil pulverisation as achieved after by combined one pass with a mouldboard plow, two passes with a disk harrow, and one pass with a spike tooth harrow. Rotavator save the time, labour and energy requirement in seed bed preparation. The objective of research was to study the effect of $\lambda$-ratio and rear shield position of the rotavator on the performance of rotavator under different field conditions namely, manually and combine harvested paddy and wheat field, for this purpose adowncut type SV- rotary tiller was selected mounted with L- shaped was used for this experiment. The rear shield position was adjustable at full down and full up positions and three variables rotor speeds viz. 212, 265 and $331 \mathrm{rpm}$ and two forward speed of tractor 2.86 and $3.57 \mathrm{~km} / \mathrm{h}$ were selected for the experiment. The studies were conducted under four different field conditions at Crop Research Centre at GBPUAT Pantnagar Uttarakhand. The result revealed that the higher value of draft, fuel consumption and power consumption were found to be $233.33 \mathrm{kgf}, 9.23 \mathrm{l} / \mathrm{h}$ and $24.92 \mathrm{~kW}$ in case of combine harvested paddy field while the lowest value of fuel and power consumption was found to be $6.70 \mathrm{l} / \mathrm{h}$ and $16.55 \mathrm{~kW}$ in manually harvested paddy field and lowest value of draft was found in manually harvested paddy field but higher value of burial residue percentage was obtained $94.20 \%$ in case of manually harvested paddy and lowest value was obtained $82.94 \%$ in combine harvested wheat.

\section{Materials and Methods}

\section{Design of the experiment}

The two factorial design was used for assessing the effect of $\lambda$ - ratio and shield positions on the performance of the rotavator under different field conditions.

\section{Design of experimental layout}

The experiment was conducted in a field with clay soil with soil particle size distribution was $62 \%$ clay, $32 \%$ silt and $6 \%$ sand. The liquid and plastic limits of the soil were $48 \%$ and $24 \%$ respectively. Four experimental plots of sizes $\left(25^{\times} 50 \mathrm{~m}^{2}\right)$ were taken at Crop 
Research Centre at G.B.P.U.A\&T Pantnagar, Uttarakhand. Adown-cutrotavator (model SV RT-70 Rotavator) was selected. A 45 hptractor equipped was used for mounting the rotavator working width of $1820 \mathrm{~mm}$ width and rotor radius $225 \mathrm{~mm}$ was used. Total forty eight L-shape type blades were mounted on the flanges of rotavator because it provided greatest thrust to the tractor. The effect of forward speed, kinematics parameter, shield positions on the performance of rotavator under different field conditions were evaluated by varying the tractor forward and rotor speeds. These speeds were achieved by adjusting the engine throttle and gear position. During testing an average depth of cut of 120 mm was maintained constant throughout the test. Two skids were used at both ends of the rotavator for control the depth of cut during testing. All the measurement was conducted after harvesting of rice (Oryza sativa L.) and wheat (Triticum aestivum) crops by manually and combine harvester machine. The burial residue efficiency by the rotavator was also evaluated during the test. However, less knowledge of how different velocities ratios of rotavator affect the distribution and incorporation of plant residues into the soil. Therefore, the objective of this research was to study the affect of independent variables like forward speed of tractor, $\lambda$-ratio and rear shield positions of the rotavator on the draft, fuel consumption, and power consumption and buried residue of crop into the soil by the rotavator under different field's conditions.

\section{Independent parameters}

The independent parameters were selected from soil, machine and field parameters. The hypothesis of testing was to assume that there will be a significant effect of $\lambda$ - ratio, shield positions on draft, fuel consumption, burial residue efficiency and power consumption by the rotavator under different field conditions. Machine parameters

\section{Kinematics parameter $(\lambda$ - ratio $)$}

$\lambda$-ratio is the dimensionless factor also known as kinematics parameter. It affected the chopping and pulverization of soil by the rotavator. Hendrick and Gill (1971c) defined that it is the dimensionless ratio of the rotor peripheral velocity to the machine forward speed.

$$
\lambda=\frac{v_{\text {cir }}}{v_{\mathrm{f}}}=\frac{R \omega}{v_{\mathrm{f}}}=\frac{2 \pi N R}{V_{f}}
$$

Where,

$$
\begin{aligned}
\mathrm{R}= & \text { Rotor radius, }(\mathrm{mm}) \\
\omega= & \text { Angular velocity of rotor, } \mathrm{rad} / \mathrm{s} \\
\mathrm{V}_{\mathrm{f}}= & \text { forward speed machine, } \mathrm{m} / \mathrm{s} \\
\mathrm{V}_{\mathrm{cir}}= & \begin{array}{l}
\text { Peripheral velocity of the rotor } \\
\text { blades, }(\mathrm{m} / \mathrm{s})
\end{array}
\end{aligned}
$$

The above formula shows that the $\lambda$ ratio varies directly with the peripheral velocity of rotor shaft varied and inversely proportional to the machine forward speed. In the experiment six different levels of the $\lambda$ values were selected at two different forward speeds of tractor viz. 2.86 and $3.57 \mathrm{~km} / \mathrm{h}$. The levels of $\lambda$-ratios are presented by $\lambda_{1}, \lambda_{2}, \lambda_{3}, \lambda_{4}$, $\lambda_{5}$ and $\lambda_{6}$ respectively.

\section{Rotational speed of the rotor}

Peripheral speed of rotor shaft was measured with contacted type tachometer until it attained three constant rotational speeds viz. 212,265 , and $331 \mathrm{rpm}$ shaft by means of variable gear box mounted on the rotavator

\section{The bite length}

Bite length $\left(\mathrm{L}_{\mathrm{b}}\right)$ is one of the principal technological parameters of the rotavator (Chamen, Cope and Patterson, 1979) and determines how finely chopped processed soil 
will be achieved (Sineokov and Panov, 1978) as shown in figure 1 . The value of $\mathrm{L}_{b}$ is given by:

$\mathrm{L}_{\mathrm{b}}=\mathrm{V}_{\mathrm{f}} \mathrm{t}_{\mathrm{b}}$

Where, $\mathrm{V}_{\mathrm{f}}=$ Forward speed, $\mathrm{m} / \mathrm{s}$; $t_{b}=$ time during which the blades rotate through an angle, equal to the angle between the adjacent blades on the same sides of a flanges. If the number of blades in one plane of rotor flange is $z$, the angle between adjacent blades is $\frac{2 \pi}{z}$ radians. In such a case, the time $t_{b}$ is given by $t_{b}=\frac{2 \pi}{z \omega}$ and the bite length $\left(\mathrm{L}_{\mathrm{b}}\right)$ is expressed as:

$$
\mathrm{L}_{\mathrm{b}}=\frac{2 \pi V_{\mathrm{f}}}{7(\omega)}=\frac{2 \pi \mathrm{R}}{\lambda_{7}}
$$

This equation shows that the bite length is a constant quantity that is dependent on the rotavator radius $(\mathrm{R})$, the number of blades on the same side of a flange ( $\mathrm{z}$ ) and the kinematics parameter $(\lambda)$.

\section{Draft of rotavator}

Draft of the rotavator was measured with the help of strain gauge type transducer. It was mounted between the two tractors as shown in figure 2. The draft was calculated at two forward speed of tractor viz. $2.86 \& 3.57$ $\mathrm{kmh}^{-1}$ for three different rotational speeds of rotor shaft in two conditions of shield positions of rotavator (up and down positions) under four different field conditions. The data was recorded in the data acquisition system as shown in figure 2.

\section{Fuel consumption by the rotavator}

Fuel consumption was measured with fuel flowmeter sensor in different field's conditions. The range of fuelmeter was 0.5 to $25.0 \mathrm{l} / \mathrm{h}$. The flow meter was attached with fuel supply system of the tractor, its input hose pipe was connected to the output to the output hose pipe of the fuel delivery line as shown in Figure 3. The output of flow meter was connected with a $\mathrm{T}$ Joint whose lateral hose deliver the fuel to the engine through a pipe. The fuel which passes through the lateral hose was measured by the flow meter which shows the consumption of diesel fuel for the total operating time. The unused diesel which returned back through the return line was joined with the longitudinal hose of the $T$ joint. Thus, the part of premeasured fuel does not go back into the fuel tank or to the flow meter. The data was recorded in the data acquisition system and presented in Table 6 .

\section{Torque measurement}

The PTO torque delivered was measured by rotary torque senor shown in fig. 4 which was mounted on the PTO shaft. PTO speed was measured with the proximity switch and an iron sprocket mounted on the shaft. The PTO torque and rotary speed pulses were recorded in variable frequency display which was recorded in the data acquisition system by portable USB cable. The power consumed by rotavator was calculated by putting the value of torque and PTO speed in formula was given below. Each test was replicated three times for each of four different field conditions. Power is the work done per unit time. So

$\mathrm{P}=\frac{d W}{d t}=\tau \frac{d \theta}{d t}=\tau \omega$

$\mathrm{P}(\mathrm{kW})=\frac{\tau(N-m) \times 2 \pi \times r p m}{60 \times 1000}$

\section{Wheel slip}

The wheel slip was measured by making a mark on the tractor and power drive wheels with coloured tape and measuring the distance travelled by wheels for particular revolutions (say 25 revolutions) under no load and with 
the same number of revolutions covered under load condition. The slip was calculated as the formula was given below.

$\operatorname{slip} \%=\frac{V_{1-} V_{2}}{V_{2}} \times 100$

Where:

$\mathrm{V}_{1}=$ Speed at no load, $\mathrm{m} / \mathrm{s}$

$\mathrm{V}_{2}=$ Speed at load condition, $\mathrm{m} / \mathrm{s}$

The observed slip was in range of 10-17\%. The respective engine speed was

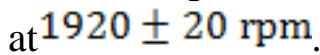

\section{Soil parameter}

\section{Moisture content (d.b \%)}

Soil samples were collected randomly from each field at the depth of $12 \mathrm{~cm}$ by using the fabricated core sampler at each depth for the determination of the moisture content of the soil. Three samples of soil were taken randomly from each four fields. To measure the moisture content of soil, soil samples were taken up to a depth of $12 \mathrm{~cm}$ was weighted. The samples were kept in an oven for 24-h at $105^{\circ} \mathrm{C}$. The weights of oven dried samples were taken out after $24 \mathrm{hrs}$. The difference in the weight loss of soil sample after oven dried gave the mass of water. The details are given in Table 3. Moisture content in dry basis was expressed in percentage was calculated by using the following equation.

Moisture content (d. b), $\%=\frac{\mathrm{M}_{\mathrm{W}}}{\mathrm{M}_{\mathrm{g}}} \times 100$

Where:

$\mathrm{M}_{\mathrm{w}}=$ Mass of water, $\mathrm{g}$

$$
\mathrm{M}_{\mathrm{s}}=\text { Mass of solids, } \mathrm{g}
$$

The moisture content was in range of $11.85 \%$ to $16.37 \%$ under all field conditions.

\section{Bulk density}

The experiment was carried out in Tarai region soils. The soil types include clay loam, silty clay loam and loam. Three samples of soil were taken randomly from four different field conditions were collected by using the fabricated core sampler at the depth of $11 \mathrm{~cm}$ for the determination of the bulk density of the soil before started experiment. The details are given in Table 3. It was determined as

$$
\text { Bulk density, } \mathrm{g} / \mathrm{cc}=\frac{\text { Weight of oven dried soil sample, }, \mathrm{g}}{\text { Volume of cyclinderical core sampler, } \mathrm{cc}}
$$

The bulk density of soil varied between 0.90 $\mathrm{g} / \mathrm{cc}$ to $1.28 \mathrm{~g} / \mathrm{cc}$ under all field conditions.

\section{Cone index}

Soil resistance was measured with the help of a proving Ring Type Cone Penetrometer of model-BL250Ec, (Baker Mercer type C-10), with least count of $0.002 \mathrm{~mm}$ and cone base diameter of $26.18 \mathrm{~mm}$. The base cone angle of the Penetrometer was $30^{\circ}$ with base area $5.38 \mathrm{~cm}^{2}$. The Penetrometer was forced into the soil up to $15 \mathrm{~cm}$ depth and corresponding dial reading was noted. The cone index was calculated by using the following relationship. The average value of cone index was obtained $1.648 \mathrm{~kg} / \mathrm{cm}^{2}$ as shown in Table 4.

Cone index, $\mathrm{kg} / \mathrm{cm}^{2}=0.025 \times$ dial reading (divisions) +0.099 .

\section{Clod mean weight diameter}

The clod mean-weight-diameter of the soil aggregate was determined by Taylor's method. M.S. iron frame of $500 \times 500 \mathrm{~mm}$ size was placed at three different places in the test area. The soil samples enclosed within the fame were collected completely up to the 12 $\mathrm{cm}$ depth of operation. The sample was passed through a set of sieves having different size of openings. The sieves were oscillated 
mechanically with the help of a set of gears provided in the unit for five minutes. All the three major axes dimensions of clods retained on the top sieves were measured and geometric mean diameter was worked out. The weight of the soil sample retained on each sieves was weighted. The clod mean weight diameter of the soil was determined by using the equation. The clod mean weight diameter of each soil type is given in Table 3 . It ranged from 23.69 to $40.08 \mathrm{~mm}$

$D_{s c}=\frac{5 A+15 B+25 C+35 D+45 E+N F}{W}$

Where,

$\mathrm{D}_{\mathrm{sc}}=$ Clod mean diameter of soil, $\mathrm{mm}$

$\mathrm{W}=$ Total weight of the soil retained on the sieve, kg.; A, B, C, D, E

$\mathrm{F} \quad=$ Weight of soil on each sieve, $\mathrm{kg}$

$\mathrm{N}=$ Mean of measured diameters of soil clods retained on the largest aperture sieve, $\mathrm{mm}$

\section{Straw burial}

The rate of straw burial was measured following method adopted by Dursun et al. (1999) using a square frame $1 \mathrm{~m}^{2}$ as shown in figure 5 .

$$
\mathrm{B}=\frac{\left(A_{1}-A_{2}\right)}{A_{1}} \times 100
$$

Where

$\mathrm{B}=$ burial straw, $\%$

$\mathrm{A}_{1}=$ Total weight of straw before tillage per square meter area,g

$\mathrm{A}_{2}=$ Buried weight of straw after tillage per square meter area, $\mathrm{g}$

\section{Results and Discussion}

\section{Effect of $\lambda$ - ratio on bite length of rotavator}

The bite length cut by the rotavator blade of rotavator is affected by $\lambda$ - ratio. The bite length is decreased linearly with an increase in value of $\lambda$-ratio as shown in figure 7 . The regression analysis showed that valueof $R^{2}$ was 0.94 .

\section{Effect of $\lambda$ - ratio and shield position on draft of rotavator}

The average value draft was decreased from (184 to $169.24 \mathrm{kgf}$ ) when the shield in raised position was more than the average value of draft decreased from(175.83to $159.41 \mathrm{kgf}$ ) when the shield in lower position under all field conditions with the average increases in $\lambda$ values (6.37 to7.98). The highest value of draft was $223.33 \mathrm{kgf}$ for lowest average value of $\lambda(6.37)$ was observed when the shields in raised position in combine harvested paddy field. The lowest value of average draft was $122.00 \mathrm{kgf}$ for highest average value of $\lambda$ (7.98) was observed when shield in lower position in manually harvested paddy as shown in Figure 6 and 7. The data was tabulated in Table 6. The statistical analysis of data revealed that there is significantly effect of $\lambda$-ratio and shield position on draft required under different field's condition as shown in Table $7 \mathrm{a}$ and $7 \mathrm{~b}$ respectively with $5 \%$ of confidence limit. This could be the due to fact that the down cutting soil rotavator may exert a forward force or thrust to the tractor driveline during operation consequently reduced the draft of the rotavator with increases of $\lambda$ value furthermore which decreased the bite length cut by the rotavator blades, but it was seen that the value of draft was found to be more when shield in full raised position as compared to shield in fully down position because the volume of soil wedge cut by the blades of rotavator was 
impacted against the lower shield position which developed a horizontal force toward the direction of travel and acts as pushing force thus reduced the draft.

\section{Effect of $\lambda$ - ratio, shield position on fuel consumption}

The average value of fuel consumption was decreased from $(8.645 \mathrm{l} / \mathrm{h}$ to $7.575 \mathrm{l} / \mathrm{h})$ when shield in lower position as compared to the average value of fuel consumption from ( 7.7 to $7.23 \mathrm{l} / \mathrm{h}$ ) when shield in raised position under all field conditions as shown in Table 6 . The result showed that the value of fuel consumption was increased when the forward speed of tractor decreased from (3.57 to 2.86 $\mathrm{km} / \mathrm{h}$ ) and also we say that it value decreased with increases in value of $\lambda$ - ratio. The higher value of average fuel consumption was found to be $9.23 \mathrm{l} / \mathrm{h}$ for combine harvested paddy with average lowest value of $\lambda(6.37)$ for lower shield position and lowest value of fuel combustion was found to be $6.70 \mathrm{l} / \mathrm{h}$ for average highest value of $\lambda$ (7.98) for manually harvested wheat for raised shield position as shown in figure 8 and 9.The reasons was that in combine harvested field the length of stubble remain in field is more in height as compared to manually harvested field which cut the crop at near its bottom furthermore more energy require in chopping process of soil and crop residue by the blades.

The higher values of kinematic parameter $(\lambda)$ the number of succeeding blades, which passed through the undisturbed soil cross section increased due to which causes the cycloid of cutting blade comes closer consequently the rotor blade cut the soil and crop residue into smaller volume which reduced fuel consumption. The statistical analysis of data revealed that there is significantly effect of $\lambda$-ratio and shield position on fuel consumption under different field's condition as shown in Table 7 cand $7 d$ respectively with $5 \%$ of confidence limit.

\section{Effect of ratio and shield position on power consumption}

The average value of power consumption was increased (21.06 to $22.00 \mathrm{~kW}$ ) when shield in lower position while the average value of power consumption increased from (20.05 to $21.36 \mathrm{~kW}$ ) when shield in raised position. The result revealed that the value of power consumption increased with increases of $\lambda$ values (6.67 to 7.98) as shown in Table 6. The higher value of average power consumption was found to be $24.92 \mathrm{~kW}$ when shield in lower position for combined harvested field with average higher value of $\lambda$ (7.98). The lower value of power consumption was found to be $16.55 \mathrm{~kW}$ when shield in raised position for average lowest value of $\lambda(6.37)$ as shown in figure 10 and 11 . The statistical analysis of data revealed that there is significantly effect of $\lambda$-ratio and shield position on power consumption under different field's condition as shown in Table 7 cand $7 \mathrm{~d}$ respectively with $5 \%$ of confidence limit. The higher power requirement at higher rotor speed could be explained by the fact that increasing kinematic parameter $(\lambda)$ by increasing angular velocity $(\omega)$ resulted in higher velocity of soil particles that increased the throw and impact against the shield cover.

\section{Effect of $\lambda$ - ratio and shield position on straw burial by the rotavator into soil}

The average percentage burial residue was increased from (88.42 to $91.27 \%$ ) when shield in lower position while the average percentage burial residue increased from (87.71 to $88.52 \%$ ) when shield in raised position under all field conditions as shown in Table 6 . The result show that the percentage burial residue was increased with increases average value of $\lambda$ (6.37 to 7.98). The higher value of average percentage of burial residue was found to be 94.20 \%for manually harvested paddy field when shield in lower 
position with average highest value of $\lambda$ (7.98). The lower value of average percentage of burial residue was found to be $82.94 \%$ for combine harvested wheat field when shield in raised position with average lowest value of $\lambda(6.37)$ as shown in figure 12 and 13 respectively because the length of stubble remained after combine harvested were more in length as compared to manually harvested crop due to which less burial residue efficiency obtained in combine harvested field. The statistical analysis of data revealed that there is significantly effect of $\lambda$-ratio and shield position on percentage of straw buried by rotavator under different field's condition as shown in Table $7 \mathrm{e}$ and $7 \mathrm{f}$ respectively with $5 \%$ of confidence limit. The reason of this is due to decrease in bite cut or an increase in soil cutting frequency when $\lambda$ ratio increased. The increased $\lambda$ value causes the cycloid of cutting blade comes closer consequently the rotor blade cut the soil and crop residue into smaller bite length and which strike the lower shield of rotavator and converted in fine particles and mixing into soil very finely. A similar pattern has been reported by Destain and Houmy (1990) who was studied the effect of the rotary tiller on soil structure.

Table.1 List of explanatory variables, their notations, units and operating levels

\begin{tabular}{|c|c|c|c|c|c|c|c|}
\hline SI.No & Name of variable & Notation & Unit & \multicolumn{4}{|c|}{ levels } \\
\hline 1 & Forward speed & $\mathrm{V}_{\mathrm{f}}$ & $\mathrm{km} / \mathrm{h}$ & 2.86 & 3.57 & - & - \\
\hline 2 & Shield positions & $\mathrm{S}$ & - & $S_{\text {up }}$ & $\mathrm{S}_{\mathrm{dn}}$ & - & - \\
\hline \multirow[t]{2}{*}{3} & \multirow[t]{2}{*}{ Kinematic parameter } & \multirow[t]{2}{*}{$\lambda$} & \multirow[t]{2}{*}{ dimensionless } & $\lambda_{1}$ & $\lambda_{2}$ & $\lambda_{3}$ & \\
\hline & & & & $\lambda_{4}$ & $\lambda_{5}$ & $\lambda_{6}$ & \\
\hline \multirow[t]{5}{*}{4} & \multirow{5}{*}{ Field condition } & $\mathrm{C}$ & Combine & \multirow[t]{5}{*}{ CHP } & \multirow[t]{5}{*}{ CHW } & \multirow[t]{5}{*}{ MHP } & \multirow[t]{5}{*}{ MHW } \\
\hline & & $\mathrm{H}$ & Harvested & & & & \\
\hline & & M & Manually & & & & \\
\hline & & $\mathrm{P}$ & Paddy & & & & \\
\hline & & W & Wheat & & & & \\
\hline
\end{tabular}

Table.2 List of response variables, their notation and units

\begin{tabular}{|l|l|l|l|}
\hline Sl.No & Name of variable & Notation & units \\
\hline $\mathbf{1}$ & Draft & D & $\mathrm{kgf}$ \\
\hline $\mathbf{2}$ & Fuel consumption & FC & $\mathrm{l} / \mathrm{h}$ \\
\hline $\mathbf{3}$ & Power consumption & PC & $\mathrm{kW}$ \\
\hline $\mathbf{4}$ & Burial residue & BR & $\%$ \\
\hline
\end{tabular}

Table.3 Bulk density of experimental field

\begin{tabular}{|l|l|l|c|c|}
\hline $\begin{array}{l}\text { Sl. } \\
\text { No. }\end{array}$ & $\begin{array}{l}\text { Field } \\
\text { Condition }\end{array}$ & $\begin{array}{l}\text { Bulk Density, } \\
\text { g/cc }\end{array}$ & $\begin{array}{l}\text { Moisture content \% } \\
\mathbf{W}=\frac{M w}{M s} \times \mathbf{1 0 0}\end{array}$ & $\begin{array}{l}\text { Clod mean } \\
\text { Diameter, mm }\end{array}$ \\
\hline $\mathbf{1}$ & CHP & 1.13 & 14.58 & 35.87 \\
\hline $\mathbf{2}$ & CHW & 1.28 & 16.37 & 40.08 \\
\hline $\mathbf{3}$ & MHP & 1.04 & 13.48 & 29.67 \\
\hline $\mathbf{4}$ & MHW & 0.90 & 11.85 & 23.69 \\
\hline
\end{tabular}


Table.4 Cone index values of experimental field

\begin{tabular}{|c|c|c|c|c|c|c|c|c|}
\hline \multirow{3}{*}{$\begin{array}{l}\text { Sl. } \\
\text { No. }\end{array}$} & \multirow{3}{*}{$\begin{array}{l}\text { Field } \\
\text { condition }\end{array}$} & \multicolumn{7}{|c|}{ Cone Index , kg/cm ${ }^{2}$} \\
\hline & & \multicolumn{6}{|c|}{ Depths, cm } & \\
\hline & & 2.5 & 5 & 7.5 & 10 & 12.5 & 15 & \\
\hline & & $\mathbf{R}_{1}$ & $\mathbf{R}_{2}$ & $\mathbf{R}_{\mathbf{3}}$ & $\mathbf{R}_{4}$ & $\mathbf{R}_{5}$ & $\mathbf{R}_{6}$ & Average \\
\hline 1. & CHP & 0.59 & 1.59 & 1.89 & 1.93 & 1.96 & 2.02 & 1.663 \\
\hline 2. & CHW & 0.62 & 1.79 & 1.85 & 1.95 & 1.98 & 2.10 & 1.715 \\
\hline 3. & MHP & 0.58 & 1.52 & 1.75 & 1.90 & 1.93 & 1.94 & 1.603 \\
\hline 4. & MHW & 0.58 & 1.54 & 1.78 & 1.89 & 1.94 & 1.96 & 1.615 \\
\hline \multicolumn{2}{|c|}{ Average } & 0.59 & 1.61 & 1.82 & 1.92 & 1.95 & 2.00 & 1.648 \\
\hline
\end{tabular}

Table.5 Kinematics parameter and bite length values at different forward and rotational speed of a rotavator under different field conditions

\begin{tabular}{|c|c|c|c|c|c|c|c|c|c|c|}
\hline S.N & $\begin{array}{l}\text { field } \\
\text { condition }\end{array}$ & 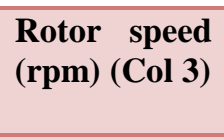 & $\begin{array}{l}\mathbf{V}_{\text {forward }} \\
(\mathbf{k m} / \mathbf{h}) \\
(\mathrm{Col} 4)\end{array}$ & $\begin{array}{l}\text { Shie } \\
\text { posi } \\
\text { (col }\end{array}$ & & $\begin{array}{l}\mathbf{V}_{\text {circular }} \\
(\mathrm{m} / \mathbf{s}) \\
(\text { col 6) }\end{array}$ & $\begin{array}{c}\lambda- \\
\text { ratio } \\
\text { level }\end{array}$ & $\begin{array}{l}\lambda \text {-ratio } \\
\text { col 6/col4 }\end{array}$ & $\begin{array}{l}\text { Bite length } \\
(\mathrm{cm})\end{array}$ & $\begin{array}{l}\text { Depth of } \\
\text { cut }(\mathrm{cm})\end{array}$ \\
\hline 1 & CHP & 212 & 2.86 & $\mathrm{~S}_{\mathrm{up}}$ & $\mathrm{S}_{\mathrm{dn}}$ & 5.10 & $\lambda_{1}$ & 6.30 & 7.4 & 12 \\
\hline 2 & & 265 & & & & 6.36 & $\lambda_{2}$ & 7.86 & 5.9 & 12 \\
\hline 3 & & 331 & & & & 7.94 & $\lambda_{3}$ & 9.80 & 4.8 & 12 \\
\hline 4 & & 212 & 3.57 & $\mathrm{~S}_{\mathrm{up}}$ & $\mathrm{S}_{\mathrm{dn}}$ & 5.10 & $\lambda_{4}$ & 5.08 & 9.2 & 12 \\
\hline 5 & & 265 & & & & 6.36 & $\lambda_{5}$ & 6.24 & 7.5 & 12 \\
\hline 6 & & 331 & & & & 7.94 & $\lambda_{6}$ & 7.79 & 6.0 & 12 \\
\hline 1 & CHW & 212 & 2.86 & $S_{\text {up }}$ & $S_{\mathrm{dn}}$ & 5.10 & $\lambda_{1}$ & 6.30 & 7.4 & 12 \\
\hline 2 & & 265 & & & & 6.36 & $\lambda_{2}$ & 7.86 & 5.9 & 12 \\
\hline 3 & & 331 & & & & 7.94 & $\lambda_{3}$ & 9.80 & 4.8 & 12 \\
\hline 4 & & 212 & & $\mathrm{~S}_{\text {up }}$ & $S_{\mathrm{dn}}$ & 5.10 & $\lambda_{4}$ & 5.08 & 9.2 & 12 \\
\hline 5 & & 265 & 3.57 & & & 6.36 & $\lambda_{5}$ & 6.24 & 7.5 & 12 \\
\hline 6 & & 331 & & & & 7.94 & $\lambda_{6}$ & 7.79 & 6.0 & 12 \\
\hline 1 & MHP & 212 & 2.86 & $S_{\text {up }}$ & $\mathrm{S}_{\mathrm{dn}}$ & 5.10 & $\lambda_{1}$ & 6.30 & 7.4 & 12 \\
\hline 2 & & 265 & & & & 6.36 & $\lambda_{2}$ & 7.86 & 5.9 & 12 \\
\hline 3 & & 331 & & & & 7.94 & $\lambda_{3}$ & 9.80 & 4.8 & 12 \\
\hline 4 & & 212 & 3.57 & $S_{\text {up }}$ & $\mathrm{S}_{\mathrm{dn}}$ & 5.10 & $\lambda_{4}$ & 5.08 & 9.2 & 12 \\
\hline 5 & & 265 & & & & 6.36 & $\lambda_{5}$ & 6.24 & 7.5 & 12 \\
\hline 6 & & 331 & & & & 7.94 & $\lambda_{6}$ & 7.79 & 6.0 & 12 \\
\hline 1 & MHW & 212 & 2.86 & $S_{u n}$ & $\mathrm{~S}_{\mathrm{dn}}$ & 5.10 & $\lambda_{1}$ & 6.30 & 7.4 & 12 \\
\hline 2 & & 265 & & & & 6.36 & $\lambda_{2}$ & 7.86 & 5.9 & 12 \\
\hline 3 & & 331 & & & & 7.94 & $\lambda_{3}$ & 9.80 & 4.8 & 12 \\
\hline 4 & & 212 & 3.57 & $S_{\text {up }}$ & $S_{d n}$ & 5.10 & $\lambda_{4}$ & 5.08 & 9.2 & 12 \\
\hline 5 & & 265 & & & & 6.36 & $\lambda_{5}$ & 6.24 & 7.5 & 12 \\
\hline 6 & & 331 & & & & 7.94 & $\lambda_{6}$ & 7.79 & 6.0 & 12 \\
\hline
\end{tabular}


Table.6 Effect of $\lambda$-ratio and shield position on draft, fuel consumption power consumption and burial residue of rotavator under different field conditions

\begin{tabular}{|c|c|c|c|c|c|c|c|c|c|c|c|c|c|}
\hline \multirow{4}{*}{$\begin{array}{l}\text { S. } \\
\mathbf{N} \\
\mathbf{1}\end{array}$} & \multirow{2}{*}{\multicolumn{5}{|c|}{ Explanatory parameters }} & \multicolumn{8}{|c|}{ Response parameters } \\
\hline & & & & & & \multicolumn{2}{|c|}{ Draft } & \multicolumn{2}{|c|}{$\begin{array}{l}\text { Fuel } \\
\text { consumption }\end{array}$} & \multicolumn{2}{|c|}{$\begin{array}{c}\text { Power } \\
\text { consumption }\end{array}$} & \multicolumn{2}{|c|}{ Burial Residue ,\% } \\
\hline & \multirow{2}{*}{$\begin{array}{l}\text { Plots } \\
\text { CHP }\end{array}$} & \multirow{2}{*}{$\begin{array}{r}\mathbf{V}_{\mathbf{f}}(\mathbf{k m m h} \\
2.86\end{array}$} & \multicolumn{2}{|c|}{$\begin{array}{c}\text { Shield } \\
\text { position }\end{array}$} & \multirow{2}{*}{$\begin{array}{c}\lambda- \\
\text { ratio } \\
6.30\end{array}$} & \multirow{2}{*}{$\begin{array}{r}\begin{array}{c}\mathbf{D}_{\text {up }} \\
\text { (kgf) }\end{array} \\
220\end{array}$} & \multirow{2}{*}{$\begin{array}{r}\begin{array}{c}\mathbf{D}_{\text {dn }} \\
(\mathbf{k g f})\end{array} \\
205\end{array}$} & \multirow{2}{*}{$\begin{array}{r}\begin{array}{r}\mathbf{F C}_{\mathbf{u p}} \\
\left(\mathbf{l h}^{-1}\right)\end{array} \\
8.20\end{array}$} & \multirow{2}{*}{$\begin{array}{r}\begin{array}{r}\mathbf{F C}_{\mathbf{d n}} \\
\left(\mathbf{l h}^{-1}\right)\end{array} \\
\\
9.00\end{array}$} & \multirow{2}{*}{$\begin{array}{l}\begin{array}{l}\mathbf{P C}_{\mathbf{u p}} \\
(\mathbf{k W})\end{array} \\
23.45\end{array}$} & \multirow{2}{*}{$\begin{array}{r}\begin{array}{r}\mathbf{P C}_{\mathbf{d n}} \\
(\mathbf{k W})\end{array} \\
23.90\end{array}$} & \multirow{2}{*}{$\begin{array}{c}\begin{array}{c}\text { Burial } \\
\text { residue }_{u p} \\
(\%)\end{array} \\
84.50\end{array}$} & \multirow{2}{*}{$\begin{array}{c}\begin{array}{c}\text { Burial } \\
\text { residue }_{\mathrm{dn}} \\
(\%)\end{array} \\
85.65\end{array}$} \\
\hline & & & $\mathrm{S}_{\mathrm{up}}$ & $S_{\mathrm{dn}}$ & & & & & & & & & \\
\hline & & 2.86 & $\mathrm{~S}_{\mathrm{up}}$ & $\mathrm{S}_{\mathrm{dn}}$ & 7.86 & 210 & 190 & 7.65 & 8.00 & 24.32 & 24.87 & 88.90 & 90.00 \\
\hline & & 2.86 & $S_{\text {up }}$ & $S_{\mathrm{dn}}$ & 9.80 & 195 & 180 & 7.50 & 7.60 & 25.45 & 26.00 & 92.00 & 93.50 \\
\hline & & 3.57 & $S_{\text {up }}$ & $\mathrm{S}_{\mathrm{dn}}$ & 5.08 & 230 & 222 & 8.65 & 9.80 & 22.36 & 22.74 & 82.09 & 84.36 \\
\hline & & 3.57 & $S_{\text {up }}$ & $S_{\mathrm{dn}}$ & 6.24 & 226 & 210 & 8.38 & 9.40 & 23.30 & 23.38 & 84.35 & 85.32 \\
\hline & & 3.57 & $S_{\text {up }}$ & $S_{\mathrm{dn}}$ & 7.79 & 214 & 195 & 7.80 & 8.50 & 24.02 & 24.84 & 88.32 & 88.69 \\
\hline \multirow[t]{6}{*}{2} & CHW & 2.86 & $S_{\text {up }}$ & $S_{\mathrm{dn}}$ & 6.30 & 210 & 200 & 7.89 & 8.50 & 22.69 & 23.45 & 82.88 & 85.30 \\
\hline & & 2.86 & $\mathrm{~S}_{\text {up }}$ & $\mathrm{S}_{\mathrm{dn}}$ & 7.86 & 198 & 175 & 7.25 & 7.50 & 24.12 & 24.56 & 86.85 & 88.32 \\
\hline & & 2.86 & $S_{\text {up }}$ & $S_{d n}$ & 9.80 & 180 & 163 & 7.00 & 7.23 & 24.89 & 25.50 & 90.50 & 92.50 \\
\hline & & 3.57 & $S_{\text {up }}$ & $S_{\mathrm{dn}}$ & 5.08 & 226 & 214 & 8.50 & 9.40 & 21.33 & 22.38 & 80.20 & 84.20 \\
\hline & & 3.57 & $S_{\text {up }}$ & $S_{\mathrm{dn}}$ & 6.24 & 218 & 206 & 8.21 & 9.28 & 22.84 & 23.16 & 82.12 & 85.00 \\
\hline & & 3.57 & $S_{\text {up }}$ & $S_{\mathrm{dn}}$ & 7.79 & 205 & 188 & 7.60 & 8.20 & 23.80 & 24.63 & 86.50 & 87.50 \\
\hline \multirow[t]{6}{*}{3} & MHP & 2.86 & $S_{\text {up }}$ & $S_{d n}$ & 6.30 & 154 & 146 & 7.29 & 8.20 & 17.89 & 18.98 & 85.09 & 92.89 \\
\hline & & 2.86 & $\mathrm{~S}_{\mathrm{up}}$ & $\mathrm{S}_{\mathrm{dn}}$ & 7.86 & 140 & 120 & 6.88 & 7.00 & 18.85 & 19.54 & 87.13 & 94.52 \\
\hline & & 2.86 & $S_{\text {up }}$ & $S_{\mathrm{dn}}$ & 9.80 & 130 & 100 & 7.10 & 6.80 & 20.10 & 20.13 & 96.00 & 95.20 \\
\hline & & 3.57 & $S_{\text {up }}$ & $S_{d n}$ & 5.08 & 164 & 163 & 7.60 & 8.90 & 17.00 & 18.50 & 89.54 & 90.00 \\
\hline & & 3.57 & $S_{\text {up }}$ & $S_{\mathrm{dn}}$ & 6.24 & 158 & 152 & 7.50 & 8.50 & 17.52 & 18.90 & 91.21 & 92.69 \\
\hline & & 3.57 & $S_{\text {up }}$ & $S_{\mathrm{dn}}$ & 7.79 & 146 & 138 & 6.66 & 7.80 & 18.85 & 19.54 & 94.32 & 93.00 \\
\hline \multirow[t]{6}{*}{4} & MHW & 2.86 & $S_{\text {up }}$ & $S_{d n}$ & 6.30 & 142 & 140 & 7.10 & 7.80 & 17.42 & 18.44 & 84.46 & 90.47 \\
\hline & & 2.86 & $S_{\text {up }}$ & $\mathrm{S}_{\mathrm{dn}}$ & 7.86 & 132 & 112 & 6.75 & 6.80 & 18.00 & 19.26 & 86.50 & 92.56 \\
\hline & & 2.86 & $S_{u p}$ & $S_{\mathrm{dn}}$ & 9.80 & 120 & 092 & 6.25 & 6.50 & 19.24 & 19.59 & 94.50 & 94.63 \\
\hline & & 3.57 & $\mathrm{~S}_{\text {up }}$ & $\mathrm{S}_{\mathrm{dn}}$ & 5.08 & 140 & 150 & 7.40 & 8.50 & 15.85 & 17.23 & 89.00 & 86.00 \\
\hline & & 3.57 & $S_{\text {up }}$ & $S_{\mathrm{dn}}$ & 6.24 & 150 & 144 & 7.20 & 7.98 & 16.00 & 18.25 & 90.25 & 89.69 \\
\hline & & 3.57 & $\mathrm{~S}_{\text {up }}$ & $S_{\mathrm{dn}}$ & 7.79 & 138 & 128 & 6.94 & 7.50 & 17.82 & 19.26 & 94.68 & 91.56 \\
\hline
\end{tabular}

Table.7a ANOVA table for effect of $\lambda$-ratio, field conditions and upward shield position on draft

\begin{tabular}{|l|r|r|r|r|r|r|}
\hline \multicolumn{1}{|c|}{$\begin{array}{c}\text { Source of } \\
\text { Variation }\end{array}$} & \multicolumn{1}{|c|}{ SS } & \multicolumn{1}{c|}{ df } & \multicolumn{1}{c|}{ MS } & \multicolumn{1}{c|}{ F } & P-value & \multicolumn{1}{|c|}{ F $_{\text {crit }}$} \\
\hline $\boldsymbol{\lambda}$ - ratio & 962.6667 & 1 & 962.6667 & 10.36984 & 0.005346 & 4.493998 \\
\hline Fields & 23102.33 & 3 & 7700.778 & 82.95272 & $5.76 E-10$ & 3.238872 \\
\hline $\begin{array}{l}\lambda-\text { ratio x } \\
\text { fields }\end{array}$ & 1235 & 3 & 411.6667 & 04.43447 & 4.018895 & 3.238872 \\
\hline Error & 1485.333 & 16 & 92.83333 & & & \\
\hline Total & $\mathbf{2 6 7 8 5 . 3 3}$ & $\mathbf{2 3}$ & & & & \\
\hline
\end{tabular}


Table.7b ANOVA table for effect of $\lambda$-ratio, field condition and down shield position on draft

\begin{tabular}{|l|c|r|r|r|r|r|}
\hline $\begin{array}{l}\text { Source of } \\
\text { Variation }\end{array}$ & SS & df & \multicolumn{1}{|c|}{ MS } & F & P-value & \multicolumn{1}{|c|}{ F $_{\text {crit }}$} \\
\hline $\boldsymbol{\lambda}$-ratio & 5735.042 & 1 & 5735.042 & 40.72219 & $9.1 \mathrm{E}-06$ & 4.493998 \\
\hline Fields & 24752.46 & 3 & 8250.819 & 58.5857 & $7.55 \mathrm{E}-09$ & 3.238872 \\
\hline $\begin{array}{l}\lambda \text {-ratio } \\
\text { xfields }\end{array}$ & 103.7917 & 3 & 34.59722 & 3.245661 & 0.863194 & 3.238872 \\
\hline Error & 2253.333 & 16 & 140.8333 & & & \\
\hline Total & $\mathbf{3 2 8 4 4 . 6 3}$ & $\mathbf{2 3}$ & & & & \\
\hline
\end{tabular}

Table.7c ANOVA table for effect of $\lambda$ - ratio, field condition and upward shield position on fuel consumption

\begin{tabular}{|l|c|r|r|r|r|c|}
\hline \multicolumn{1}{|c|}{$\begin{array}{c}\text { Source of } \\
\text { Variation }\end{array}$} & SS & \multicolumn{1}{c|}{ df } & MS & F & P-value & F $_{\text {crit }}$ \\
\hline $\boldsymbol{\lambda}$-ratio & 3.038817 & 1 & 3.038817 & 50.48567 & $2.49 \mathrm{E}-06$ & 4.493998 \\
\hline Fields & 4.543817 & 3 & 1.514606 & 25.16304 & $2.68 \mathrm{E}-06$ & 3.238872 \\
\hline $\boldsymbol{\lambda}$ ratio xfields & 0.114683 & 3 & 0.038228 & 3.635101 & 0.603161 & 3.238872 \\
\hline Error & 0.963067 & 16 & 0.060192 & & & \\
\hline Total & $\mathbf{8 . 6 6 0 3 8 3}$ & $\mathbf{2 3}$ & & & & \\
\hline
\end{tabular}

Table.7d ANOVA table for effect of $\lambda$-ratio, field condition and down shield position on fuel consumption

\begin{tabular}{|l|r|r|r|r|r|c|}
\hline \multicolumn{1}{|c|}{$\begin{array}{c}\text { Source of } \\
\text { Variation }\end{array}$} & \multicolumn{1}{|c|}{ SS } & \multicolumn{1}{c|}{ df } & \multicolumn{1}{c|}{ MS } & \multicolumn{1}{c|}{ F } & P-value & F $_{\text {crit }}$ \\
\hline $\boldsymbol{\lambda}$-ratio & 10.4412 & 1 & 10.4412 & 50.576 & $2.47 \mathrm{E}-06$ & 4.493998 \\
\hline Fields & 5.049913 & 3 & 1.683304 & 8.153733 & 0.001607 & 3.238872 \\
\hline $\boldsymbol{\lambda}$-ratio xfields & 0.055946 & 3 & 0.018649 & 4.090332 & 0.964313 & 3.238872 \\
\hline Error & 3.303133 & 16 & 0.206446 & & & \\
\hline Total & $\mathbf{1 8 . 8 5 0 2}$ & $\mathbf{2 3}$ & & & & \\
\hline
\end{tabular}

Table.7e ANOVA table for effect of $\lambda$-ratio, field condition and upward shield position on power consumption

\begin{tabular}{|l|r|r|r|r|r|c|}
\hline \multicolumn{1}{|c|}{$\begin{array}{c}\text { Source of } \\
\text { Variation }\end{array}$} & \multicolumn{1}{|c|}{ SS } & \multicolumn{1}{c|}{ df } & MS & F & P-value & F $_{\text {crit }}$ \\
\hline $\boldsymbol{\lambda}$ ratio & 23.82034 & 1 & 23.82034 & 40.36747 & $9.58 \mathrm{E}-06$ & 4.493998 \\
\hline Fields & 183.1753 & 3 & 61.05844 & 103.4735 & $1.09 \mathrm{E}-10$ & 3.238872 \\
\hline $\boldsymbol{\lambda}$ ratio xfields & 0.947846 & 3 & 0.315949 & 3.535427 & 0.664635 & 3.238872 \\
\hline Error & 9.4414 & 16 & 0.590088 & & & \\
\hline Total & $\mathbf{2 1 7 . 3 8 4 9}$ & $\mathbf{2 3}$ & & & & \\
\hline
\end{tabular}


Table.7f ANOVA table for effect of $\lambda$-ratio, field condition and down shield position on power consumption

\begin{tabular}{|l|l|l|l|l|l|l|}
\hline Source of Variation & SS & df & MS & F & P-value & F crit \\
\hline $\boldsymbol{\lambda}$ - ratio & 14.122 & 1 & 14.122 & 56.56721 & $1.22 \mathrm{E}-06$ & 4.493998 \\
\hline Fields & 160.4898 & 3 & 53.49662 & 214.2865 & $3.99 \mathrm{E}-13$ & 3.238872 \\
\hline $\boldsymbol{\lambda}$ - ratio x fields & 0.949846 & 3 & 0.316615 & 3.268237 & 0.318773 & 3.238872 \\
\hline Error & 3.9944 & 16 & 0.24965 & & & \\
\hline Total & $\mathbf{1 7 9 . 5 5 6 1}$ & $\mathbf{2 3}$ & & & & \\
\hline
\end{tabular}

Table.7g ANOVA table for effect of $\lambda$-ratio, field condition and upward shield position shield position on burial residue

\begin{tabular}{|l|l|l|l|l|l|l|}
\hline Source of variation & SS & df & MS & F & P-value & F crit \\
\hline $\boldsymbol{\lambda}$ - ratio & 152.5608 & 1 & 152.5608 & 16.08717 & 0.001009 & 4.493998 \\
\hline Fields & 130.6802 & 3 & 43.56007 & 4.593303 & 0.016734 & 3.238872 \\
\hline $\boldsymbol{\lambda}$ - ratio x fields & 7.448146 & 3 & 3.482715 & 3.261796 & 0.851862 & 3.238872 \\
\hline Error & 151.7342 & 16 & 9.483388 & & & \\
\hline Total & $\mathbf{4 4 2 . 4 2 3 4}$ & $\mathbf{2 3}$ & & & & \\
\hline
\end{tabular}

Table.7h ANOVA table for effect of $\lambda$-ratio, field condition and down shield position shield position on burial residue

\begin{tabular}{|l|r|r|r|r|r|c|}
\hline Source of Variation & \multicolumn{1}{|c|}{ SS } & \multicolumn{1}{c|}{ df } & \multicolumn{1}{c|}{ MS } & \multicolumn{1}{c|}{ F } & \multicolumn{1}{c|}{ P-value } & \multicolumn{1}{c|}{ F $_{\text {crit }}$} \\
\hline $\boldsymbol{\lambda}$ - ratio & 101.7228 & 1 & 101.7228 & 30.0885 & $4.99 \mathrm{E}-05$ & 4.493998 \\
\hline Fields & 129.7525 & 3 & 43.25085 & 12.79313 & 0.000161 & 3.238872 \\
\hline $\boldsymbol{\lambda}$ - ratio x fields & 6.947112 & 3 & 3.315704 & 3.68496 & 0.574169 & 3.238872 \\
\hline Error & 54.0926 & 16 & 3.380788 & & & \\
\hline Total & $\mathbf{2 9 2 . 5 1 5 1}$ & $\mathbf{2 3}$ & & & & \\
\hline
\end{tabular}

Fig.1 Soil wedge cut by the blades of rotavator

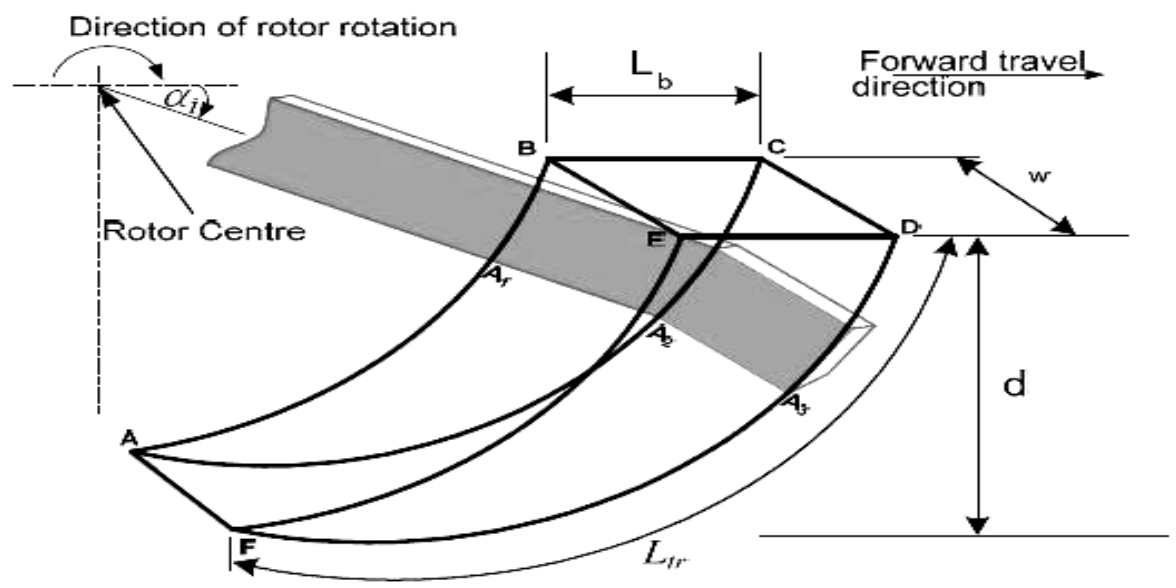


Fig.2 Draft measurement of rotavator

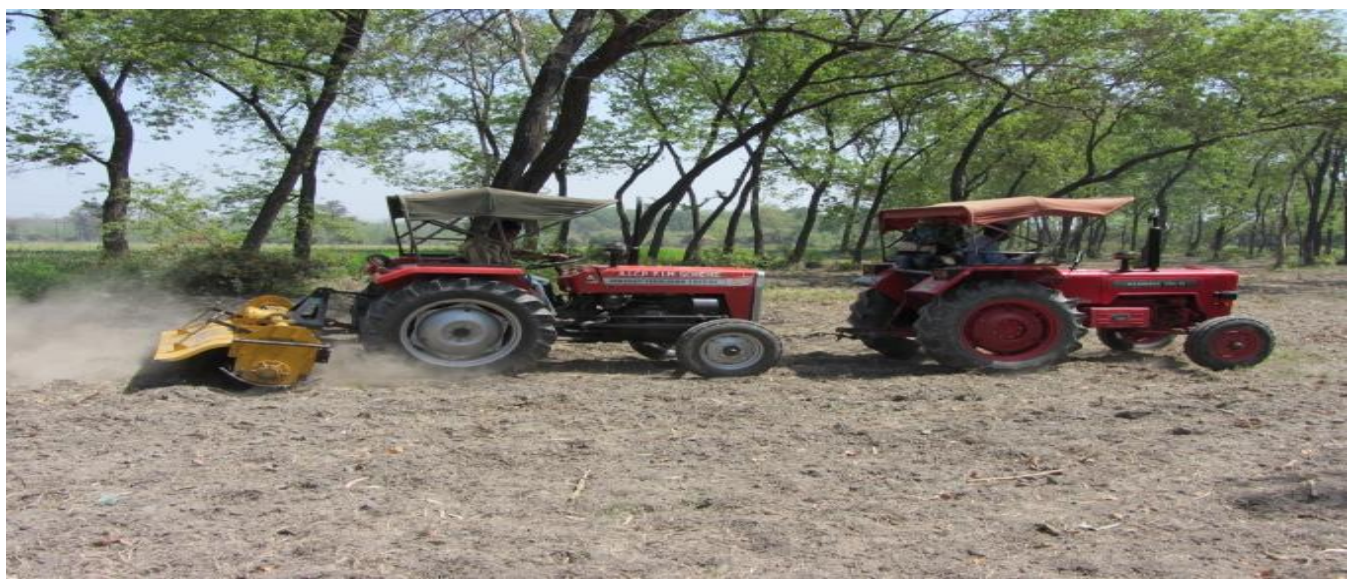

Fig.3 Fuel consumption measurement by flow meter sensor and data recorded in DAS system

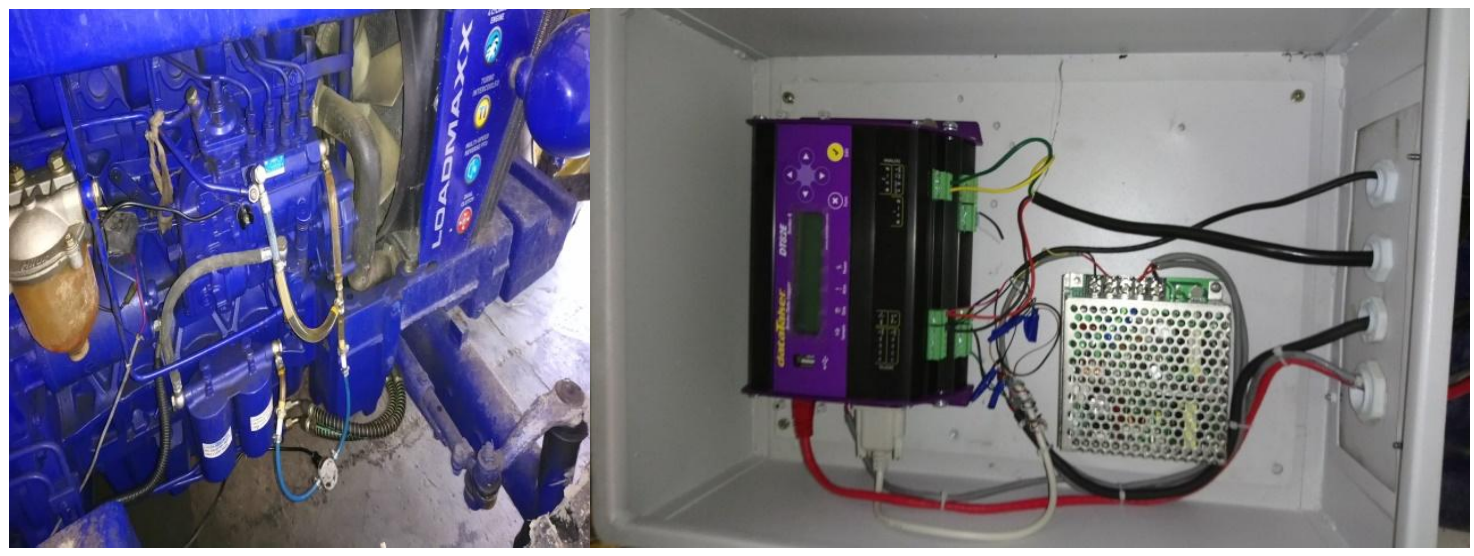

Fig.4 Set up of Torque measurement of rotavator blade by torque sensor
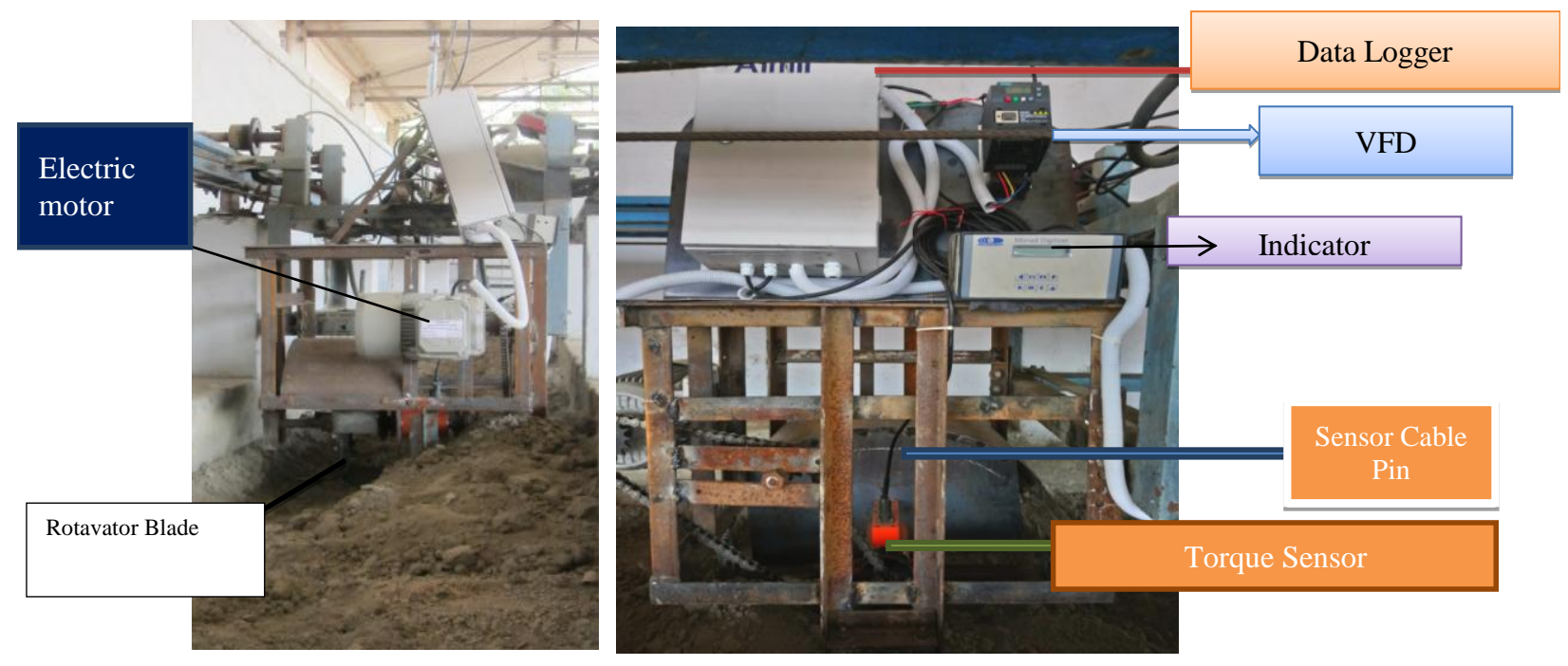
Fig.5 Counting of stubble remained after combine harvested before tillage operation

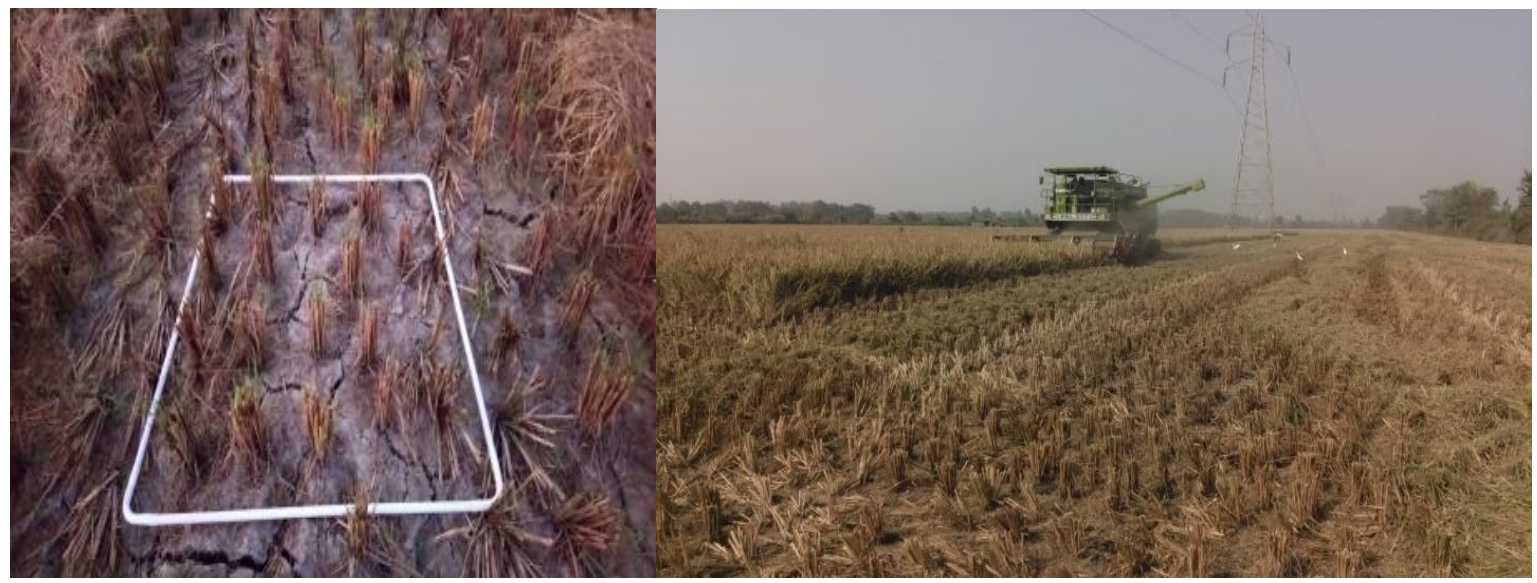

Fig.7 Effect of $\lambda$-ratio on bite cut by rotavator

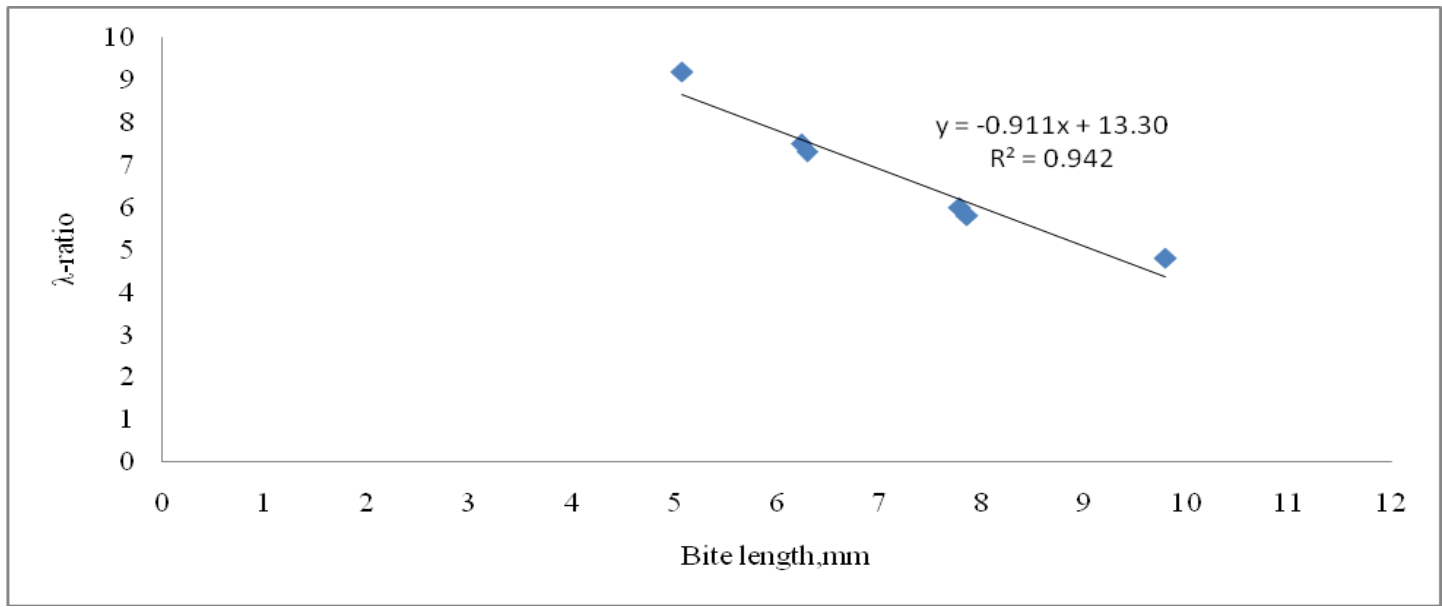

Fig.8 Effect of $\lambda$-ratio on draft of rotavator when shield kept in raised position under different field conditions

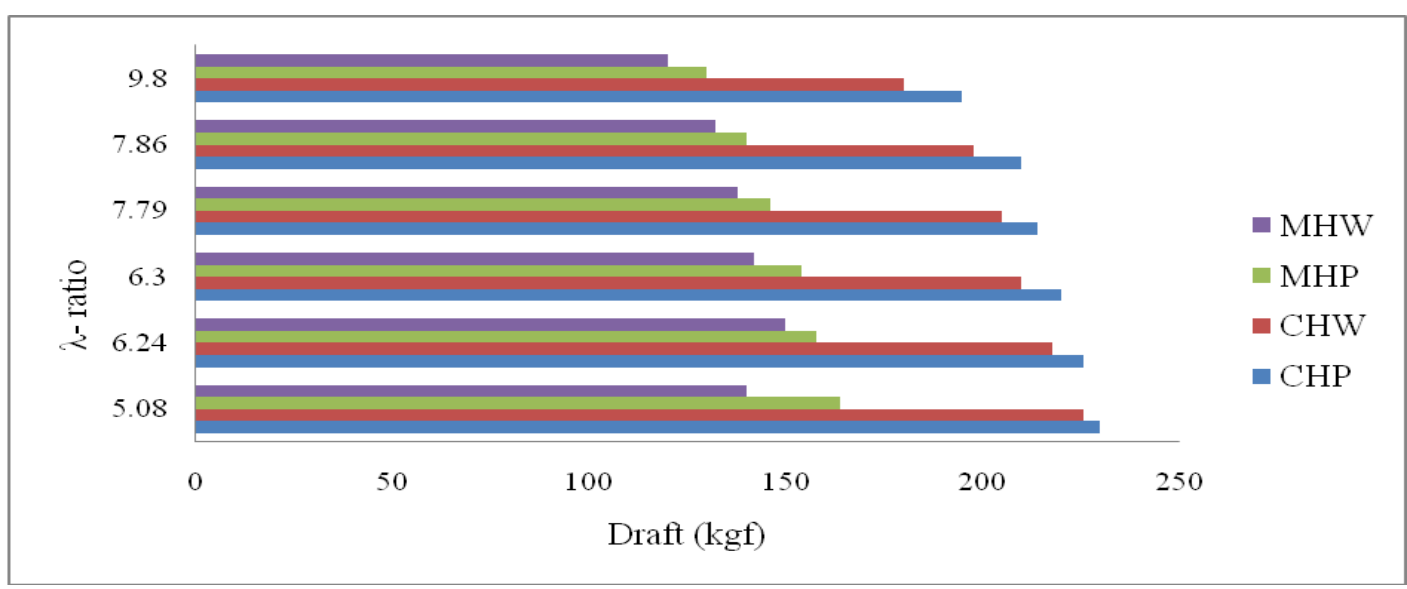


Fig.9 Effect of $\lambda$-ratio on draft of rotavator when shield kept in lowered position under different field conditions

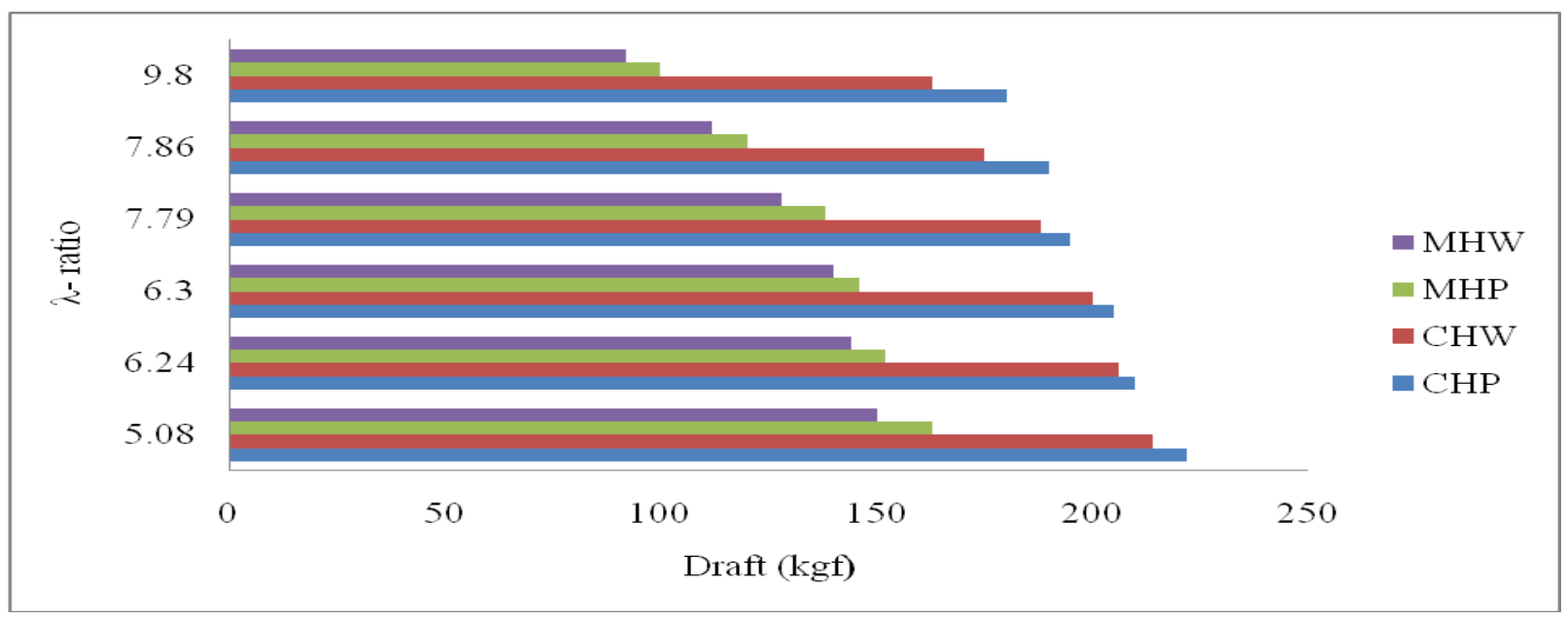

Fig.10 Effect of $\lambda$ ratio on fuel consumption of rotavator when shield kept in raised position under different field conditions

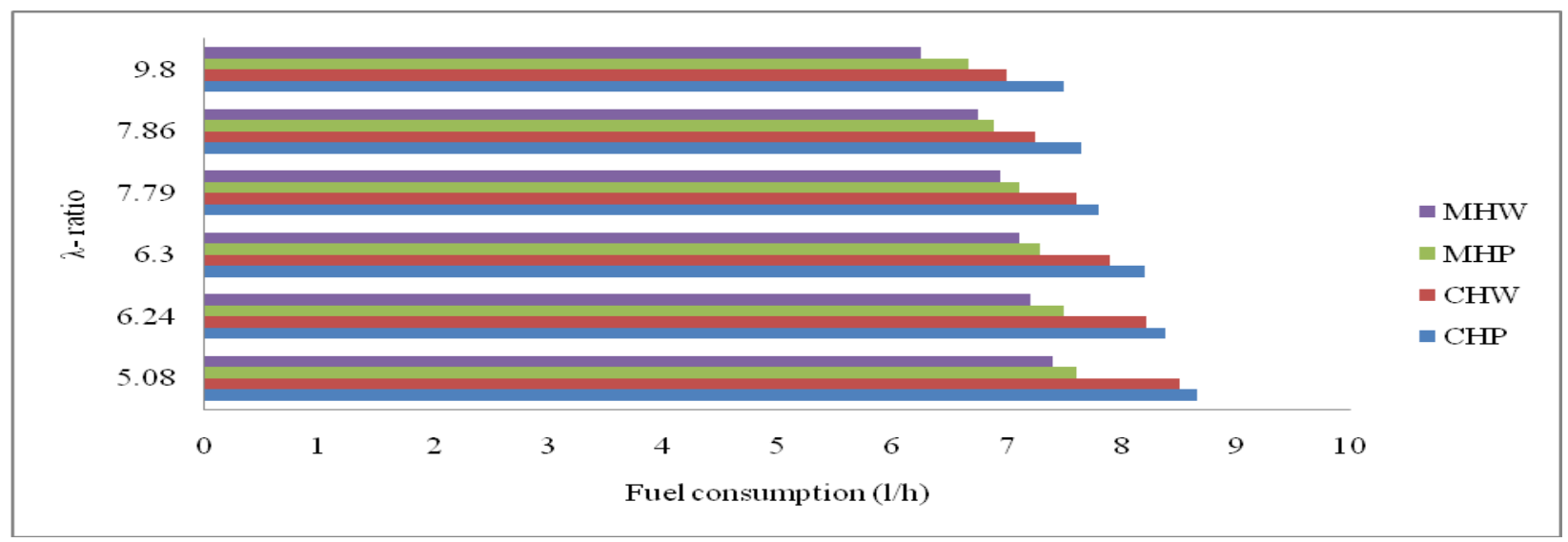

Fig.11 Effect of $\lambda$-ratio on fuel consumption of rotavator when shield kept in lowered position under different field conditions

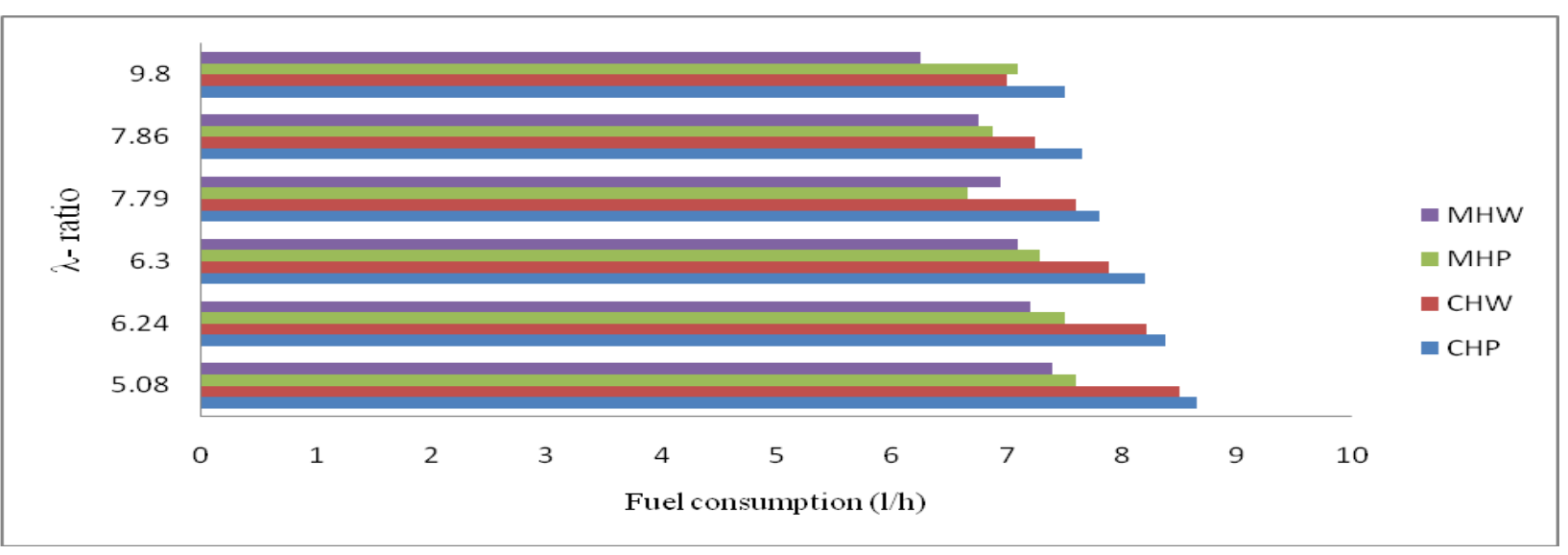


Fig.12 Effect of $\lambda$-ratio on power consumption of rotavator when shield kept in raised position under different field conditions

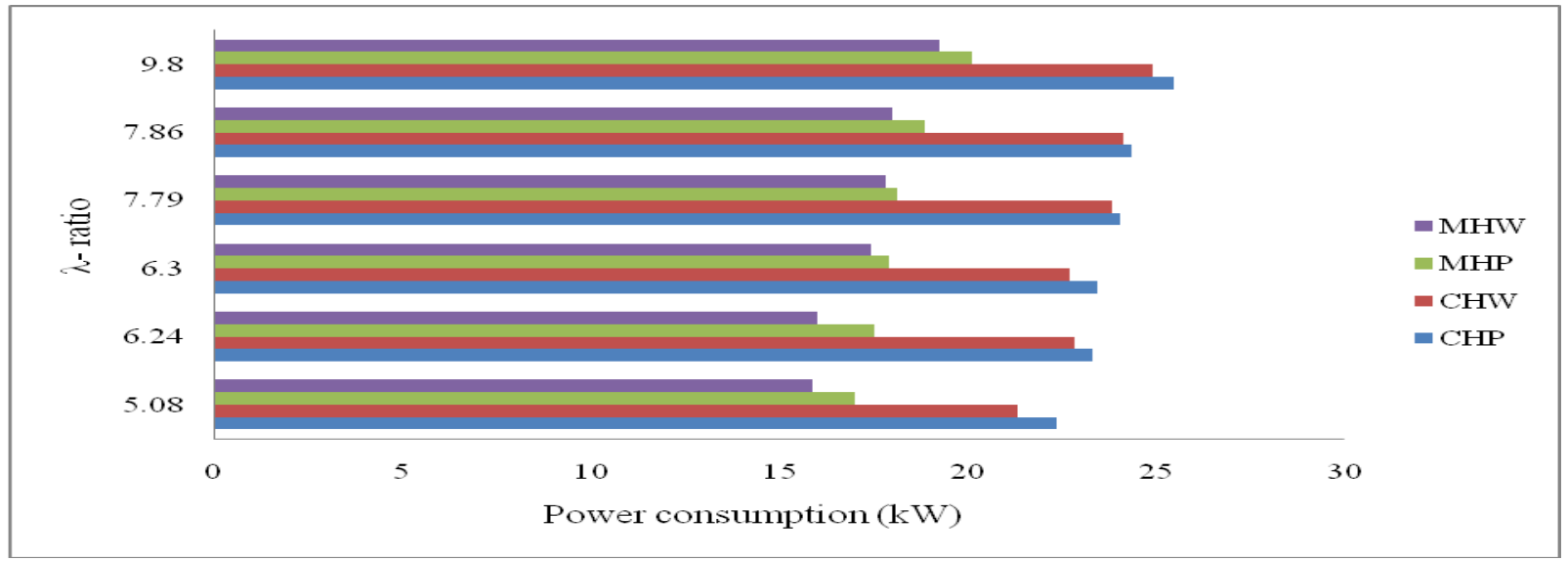

Fig.13 Effect of $\lambda$-ratio on power consumption of rotavator when shield kept in lowered position under different field conditions

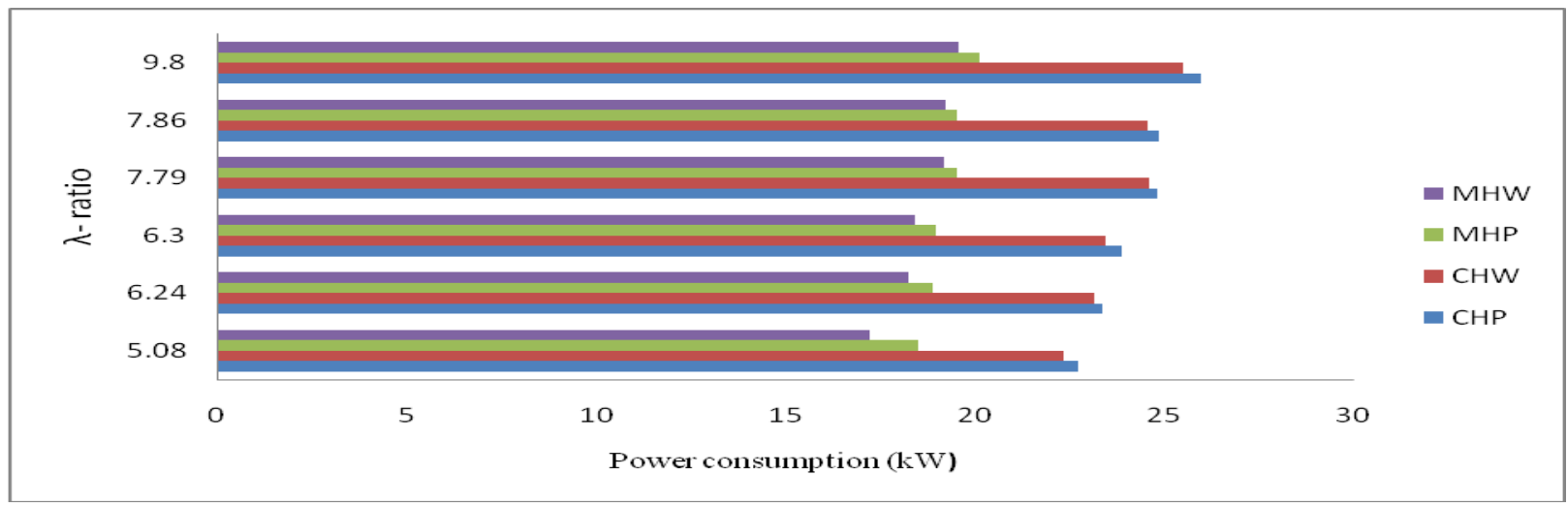

Fig.14 Effect of $\lambda$-ratio on burial residue by a rotavator when shield kept in raised position under different field conditions

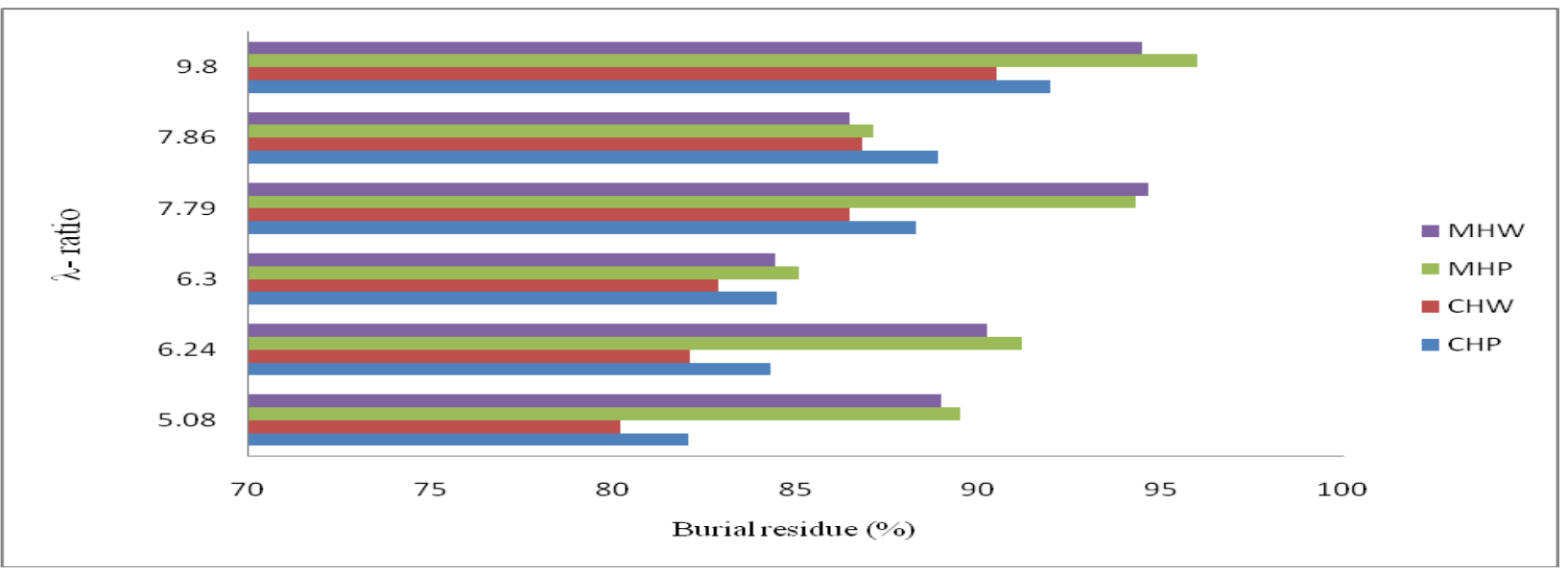


Fig.15 Effect of $\lambda$-ratio on burial residue by a rotavator when shield kept in lowered position under different field conditions

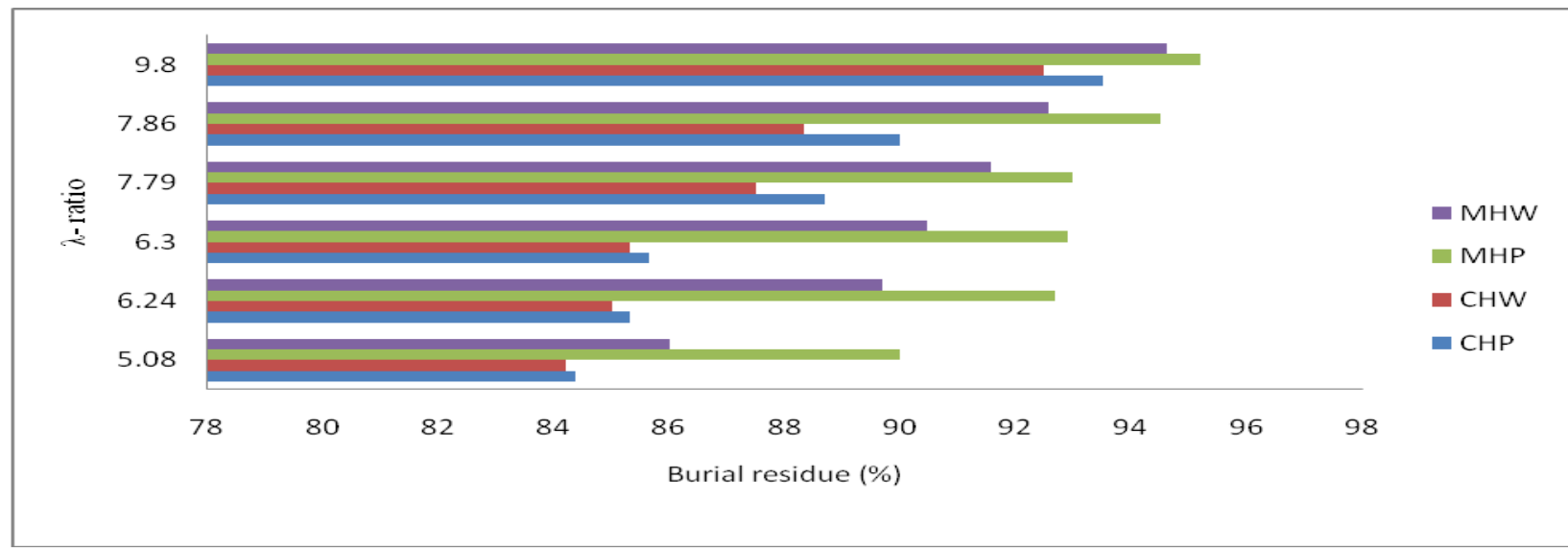

In conclusion, the effect of $\lambda$ - ratio and different shield positions were significantly effect on performance of rotavator under different field conditions. It affects the draft, fuel consumption, power consumption and straw buried capacity of rotavator. The magnitude and variations of the resultant forward thrust force generated for a down cut tillage operation depended on bite length, set tillage depth, and the kinematics parameter $(\lambda)$, shield positions and forward and rotary speed of rotavator. Therefore, the rotavator configuration and operational parameters must be controlled precisely in order to obtain the desirable performance and the effective use of resultant thrust force for a down- cut rotavator.

\section{References}

Bernacki, H., J. Haman and Cz. Kanafojski. 1972. Agricultural machines, theory and construction. US Department of Commerce, National Technical Information Service, Springfield, Virginia 22151.

Bukhari, K. H., S. Bukhari, M. M. Leghari and M. S. Memon. 1996. The effect of speed and rear shield on the performance of rotary tiller. Agricultural, Africa and Latin America
27(2):9 - 14.

Butterfield, R. and K. Z. Andrawes. 1972. On the angles of friction between sand and plane surfaces. Journal of Terramechanics, 8(4): $15-23$.

Camp, C. R and W. R. Gill. 1969. The effect of drying on soil strength parameters. Soil Sci. Am. Proc. 33: 641 - 644.

Chancellor, W. J. 1994.Chapter 2 - Soil physical properties. In: Advances in Soil Dynamics Volume 1. ASAE Monograph Number 12.

Chancellor, W. J. and J. A. Vomicil. 1971. The relation of moisture content to failure strength of seven agricultural soils. Transactions of the ASAE, 13(1): $9-13,17$

Erbach, D. C. 1987. Measurement of soil bulk density and moisture. Transactions of the ASAE, 30(4): $922-932$.

Gardner, W. H. 1986.Water Content. In Methods of soil analysis, Part I. Physical and Mineralogical Methods, $2^{\text {nd }}$ Ed., ed. A Klute, 493 - 544. Madison, Wis.: American Society of Agronomy.

Ghosh, B. N. 1967. The power requirement of a rotary cultivator. J. Agric. Eng. Res. 12(1): $5-12$.

Gill, W. R. and G. E. Vanden Berg. 1967. Soil dynamics in tillage and 
traction. Agricultural Handbook No. 316. Washington D.C., US GPO.

Gitau, A. N., Gumbe, L. O. and Biamah E. K. (2006). Influence of soil water on stress strain behaviour of a compacting soil in semi- arid Kenya. Soil and Tillage Res. 89 (2006): $144-154$.

Gupta, C. P., and R. Visvanathan.1993b. Power requirements of a rotary tiller in saturated soil. Transactions of the ASAE, 36(4): 1009 - 1012.

Hendrick, J. G. 1980.A rotary chisel. Transactions of the ASAE, pp 1349 1352.

Hendrick, J. G. and A. C. Bailey. 1982. Determining components of soil- metal friction sliding resistance. Transactions of the ASAE, 25(4): $845-849$

Hendrick, J. G. and W. R. Gill. 1978. Rotary tiller design parameters, V: Kinematics. Transactions of the ASAE, 21(4): 658 660.
Hendrick, J.G. and W.R. Gill. 1971a. Rotary tiller design parameters: Part I Direction of rotation. Transactions of the ASAE, 14(4): 669- 674, 683.

Hendrick, J.G. and W.R. Gill. 1971b. Rotary tiller design parameters: Part II - Depth of tillage. Transactions of the ASAE, 14(4): 675- 678.

Hendrick, J.G. and W.R. Gill.1974. Rotary tiller design parameters: Part IV - blade clearance angle. Transactions of the ASAE, 17(1): $4-7$.

Hendrick, J.G. and W.R. Gill. 1976. The irregularities of soil disturbance depth by circular and rotating tillage tools. Transactions of the ASAE, 19(2): 230233.

Hendrick, J.G. and W.R. Gill. 1971 c. Rotary tiller design parameters: Part III- Ratio of peripheral and forward velocities. Transactions of the ASAE, 14(4): 679 683.

\section{How to cite this article:}

Abhishek Kumar and Pateriya, R.N. 2021. Studies on Performance of a Rotavator as Affected by its $\lambda$-Ratio. Int.J.Curr.Microbiol.App.Sci. 10(02): 3053-3069.

doi: https://doi.org/10.20546/ijcmas.2021.1002.334 